\title{
Championing and promoting innovation in UK megaprojects
}

\section{Abstract}

In this article we explore the role of innovation champions and the ways innovation is championed and promoted in five selected UK megaprojects. To date, this research area is surprisingly underexplored in the megaproject management literature. The study is based on thirty interviews with innovation champions to capture their own perceptions and narratives on the ways innovation is stimulated and promoted in megaprojects, combined with relevant textual materials. Innovation was commonly defined as a step change or best practice that creates value that could be financial, environmental, societal etc. The data demonstrate the role of CEOs and their collaboration with innovation champions and academic partners in introducing innovation into the vocabulary of megaprojects, developing and formalising innovation strategy, and transferring experiences across megaprojects. The data show the ways different communication channels are used to promote innovations by champions such as forums, portals, platforms, campaigns, events etc.

Keywords: innovation, championing, communication, megaprojects, promoting

\section{Introduction}

"The interest in megaproject management has probably never been greater" (Söderlund, 2017, p. 132). Large-scale infrastructure assets such as water facilities, airports, roads, railways are complex systems that require a large investment commitment, take many years to develop and build, involve multiple public and private stakeholders, and have long-lasting impact on the economy, the environment, and society (Flyvbjerg et al., 2003; Flyvbjerg, 2017; Lundin and Söderholm, 1995; Söderlund, 2004). Whilst megaprojects may possess some repetitive features and some degree of permanency (Brookes et al., 2017), they are essentially unique, temporary special purpose organisations, where stakeholders involved tend to change their positions across megaprojects. The majority of megaprojects operate in a context of collaborative work meaning that they move away from coordinating via formal, more rigid organisational structures (e.g. rules, schedules, division of 
labour) towards an emphasis on collaborative, inter-personal coordination and informal communication mechanisms. This shift requires stronger innovation championing behaviour.

Megaprojects are fundamentally about innovation, whether it sets out to advance a technology or seeks a novel way of executing it to meet the owner's business case (Davies et al., 2009; Davies and Mackenzie, 2014). The specific characteristics of megaprojects which shape the ways innovations are championed and promoted are: (i) being bespoke or created for a specific purpose; (ii) one-off specific end date and budget agreed, but usually long life-span throughout which managers and agreed parameters (cost, time) keep changing; at the end megaproject members separate and may or may not work together on subsequent megaprojects; (iii) alliance contracting - collaborative framework, cocreative process which promotes innovation, openness, trust, etc.; (iv) substantial risks, e.g. financial, operational, reputational, innovation and uncertainties; and (v) with different organisational cultures merging together, e.g. owners, system integrators and suppliers, which shape learning practices (Gann et al., 2017; Sergeeva and Roehrich, 2018). Megaproject history in the UK, from Heathrow Terminal 5, via the Olympic Park and Crossrail towards Thames Tideway Tunnel, High-Speed Two and Hinckley Point C, provides insights into the ways innovation has been championed and promoted, placing the country in a unique position of global influence. Most British megaprojects have a small team of formal innovation managers and informal roles of innovation champions involved throughout their life cycles. They pull different organisations together in megaproject organising to ensure the innovative delivery of new assets.

We define innovation in the context of megaproject as a new product, process, or service that has a step change and creates value, e.g. financial value, environmental value, societal value, job creation etc. It may be new to a megaproject but not necessarily new to the world. The innovation potential for megaprojects is subjected to a fundamental tension: on the one hand, they offer a one-off opportunity to invest in cutting-edge innovative solutions; on the other hand, innovations are risky and in some cases could lead to failure and budget and time loss (Davies et al., 2009; Gil et al., 2012). In these settings, championing innovation is increasingly recognised as important for successful delivery of megaprojects that impacts on the policy-making, economy and society as a whole. Surprisingly, 
this area of research remains under-explored in the megaproject management literature. Little is known about the ways champions lead and promote innovations in the settings of megaprojects.

The research questions this article aims to answer are: What is the role of innovation champions in megaprojects? How are innovations championed and promoted in megaprojects from the perspectives of champions? These questions are of interest and value to the project and innovation management scholarship, as they address the gap in better understanding innovation championship in megaprojects, highlighted by Davies et al. (2009), Gil et al. (2012). To answer these questions, five megaprojects among London's most recent infrastructure megaprojects have been investigated: London 2012 Olympics, Crossrail, Bank Station Upgrade, Thames Tideway Tunnel and High Speed Two. The research is concerned with understanding practices and processes deployed by megaprojects at different stages of their life-cycle to encourage and simulate innovations to improve the megaproject performances. It is widely understood that in the UK the first stimulus to research for different ways of delivering megaprojects was provided by the Heathrow Terminal 5 (T5) in the 1990s (Davies et al., 2009). Since then, the success achieved by the London Olympics 2012 construction megaproject and the Innovation Strategy developed by Crossrail megaproject (Davies et al., 2014) have further encouraged the sector to explore the role of innovation champions, and ways innovation is championed and promoted in megaprojects.

The next section critically reviews the relevant literature on innovation in the context of megaprojects. This is followed by an overview of the research methods used, which explains the rationale behind the multi-method approach adopted and the way data were collected and analysed. The perspectives of innovation champions on the ways innovation is championed and promoted in five megaprojects are then discussed. The analysis and interpretation of the data collected against the reviewed literature is then presented. A concluding section provides an overview of key points, offering future research directions.

\section{Innovation in Megaprojects}

\subsection{Championing and promoting innovation in megaprojects}


Within the UK construction sector, a strong emphasis on the need to innovate came from the Latham (1994), Egan (1998) and Wolstenholme (2009) reports, which stressed the importance of capturing successful practices from other industries and reinforcing the weak relationships of a fragmented supply chain. As a response, the construction project management literature has since devoted great attention to the role of clients in stimulating innovation throughout the supply chain (Bossink, 2004; Orstavik et al., 2016). Winch (1998) was among the first who provided two frameworks to support managers' understanding of innovation management in the UK construction sector. The first explained the institutional context in which project-based firms innovate and the types of actors involved; whereas the second illustrates the four innovation processes carried out at intra-firm level. The author argued that gainsharing, partnering and reward systems can help shift people attention from business-as-usual to innovative practices. He also emphasised the role of innovation champions and systems integrators in managing ideas into good currency, and the role of clients in exerting institutional leadership and shaping the context within which innovation can flourish. The fundamental role owners play in organising the institutional context of projects is further highlighted by Winch (2014) and Winch and Leiringer (2015) in their argument about the dynamic capabilities of strong owners in delivering major infrastructure projects. These studies provide a starting point to understand the ways innovation is driven by permanent owner organisations in stimulating the supplier project-based firms to innovate. However, these studies fall short in exploring how key actors, innovation champions, contextualize and manage innovation in temporary megaprojects which integrate permanent owners and supplier project-based firms.

Adopting a system integration perspective, Davies et al. (2009) studied T5 megaproject working closely with senior managers to explore the ways megaproject can improve performance by learning to implement innovations based on replication of a system production processes. They conclude that "strong leadership with a coherent vision as well as the use of performance indicators and organizational change programs are essential to support new behaviours required to successful outcomes" (Davies et al., 2009, p. 121). Gil et al. (2012) examined the potential contribution of new mega infrastructure projects to innovating large socio-technical systems. It is probably Crossrail 
megaproject the first to formalise an Innovation Strategy, stimulating the research to investigate it in greater details. Based on Crossrail case study, Davies et al. (2014) developed a framework that identifies four windows of opportunity to promote innovation in a megaproject:

1. Bridging window during the front-end when innovative ideas are generated, learning and practices from other projects are used;

2. Engaging window when tendering and contractual processes are used by the client to encourage suppliers to develop innovative ideas;

3. Leveraging window when all the parties involved are mobilised to develop innovative ideas, new technologies and improvements;

4. Exchanging window at the back-end when innovative ideas can be combined with those of other projects in the innovation ecosystem.

The framework considers innovation as enabler to deliver benefits and improve megaproject performances. Building on the findings of Davies et al. (2014), further research has been made on the Crossrail project which introduces concepts of open innovation (Dodgson et al., 2015; Wornsop et al., 2016). A processual and open innovation perspectives provide an opportunity to explore innovation and learning legacy as a way of transforming the infrastructure industry over time. However, inadequate attention is given to the role of innovation champions who are enthusiastically communicate and promote innovation in megaprojects (Söderlund, 2004).

Creating and maintaining complex systems in megaprojects requires the mobilisation of a wide range of capabilities including alliance, governance, innovation, and learning (Flyvbjerg, 2017; Köhtamäki et al., 2018). Yet, very little attention has been paid to innovation capabilities and competencies of megaprojects. Drawing upon the strategy literature, Gann et al. (2017) identified five strategic processes used by managers to address the risks and opportunities involved in megaproject management:

- Search capabilities: to identify, test, and combine components of the delivery model required to address the uncertainty and achieve the goals of the project; 
- Adaptive problem-solving capabilities: By establishing project team structures and processes to deal with emergent problems and opportunities;

- Test and trial capabilities: To test novel and high-risk practices and conduct trials to ensure that new technology is proven prior to its introduction on the project;

- Strategic innovation capabilities: To create a formal and deliberate process of leverage the innovative resources and capabilities of the project supply chain and research partners;

- Balancing capabilities: To manage the trade-offs between performing planned routines and promoting innovation when unexpected events happen, new opportunities arise, or conditions change.

The identified five strategic processes provide an overview of megaproject management, focusing on strategic and formal approaches to innovation. Uncertainty is recognised as a fuel for innovation in megaprojects, a means of reducing uncertainty through time (Sanderson, 2012). Yet, scant attention is paid to informal roles of innovation champions and communication channels through which innovation is promoted in megaprojects. This paper aims to fill the gap in the innovation and megaproject literatures on innovation champions and the ways innovation is communicated and promoted internally in megaproject organisations and their alliances. The particular construction of this paper lies in understanding innovation champions' own perspectives on championing and promoting innovation in the context of megaprojects.

\subsection{The role of innovation champions in megaprojects}

The theory of innovation champions can be traced by to the work of Schon (1963) who introduced the concept of 'product champions' who promote the development of promising new inventions. Howell and Higgins (1990) investigated personality characteristics and influence tactics of champions of technological innovation based on questionnaires and interviews. Champions reported using transformational leader behaviours to a significantly greater extent than did non-champions. Champions exhibited higher risk taking and innovativeness and used greater variety of influence tactics than non-champions. Day (1994) provided an integrative view on top-down and bottom-up 
champions in developing innovative ventures; their functions and roles are differentiated. Rogers (2003, p. 414) further defines an innovation champion as "a charismatic individual who throws his or her weight behind an innovation, thus overcoming indifference or resistance that the new idea may provoke in an organisation". Innovation champions are seen as those actors who take an innovation on board, modify and 'fit' it into a context, in comparison to 'innovators' who are seen as actors who first come up with an idea.

The role of innovation champions has been recognised in construction project management research. Winch (1998) was among the first who emphasised that innovations in the UK construction sector need champions. Nam and Tatum (1997) also promoted the idea of champions for innovation and distinguished between technical, business and executive champions. According to Blayse and Manley (2004) the role of champions is to overcome uncertainty of construction innovation and resistance to innovation. Of further relevance is Leiringer and Cardellino's (2008) study of the way innovation champions mobilise rhetorical strategies retrospectively to interpret and legitimise the diffusion of innovations. Unger et al. (2014) further highlight innovation championship and incentivisation forming a corporate innovation culture. Innovation champions who strongly contribute to innovation implementation in project portfolio context by exhibiting confidence and persistence need to be supported and endorsed. In a megaproject, different groups are involved who might promote an innovation: top management, the bid team, or the project team (Brockmann et al., 2016). Davies et al. (2014) study Crossrail megaproject which established a group of innovation champions located in project and functional departments with the specialised knowledge needed to help the innovation team evaluate and select good ideas. Sergeeva (2016) explores the ways senior managers in the UK construction sector socially construct their identities as champions of innovation through stories. Yet there remains to explore different ways innovations are championed and promoted in the specific settings of megaprojects.

We build upon the extant studies and argue that innovation champions play a crucial role in stimulating and promoting innovations in megaprojects. In their informal roles, innovation champion 
can be anyone in a megaproject who is "willing to take risks by enthusiastically promoting the development and/or implementation of an innovation inside a corporation through a resource acquisition process without regard to the resources currently controlled." (Jenssen and Jörgensen, 2004, p. 65). Capable owners and suppliers need champions who enthusiastically promote innovations in megaprojects through different communication channels.

\section{Methodology}

\subsection{Research design}

A multi-case study method was used as preferred when contemporary events are to be examined within their real-world context (Yin, 2014). They may offer ground for new discoveries, starting points for future research or new insights not originally foreseen. The research investigated five case studies, selected among London's major and most recent infrastructure megaprojects: London 2012 Olympics Programme, Crossrail, Bank Station Capacity Upgrade (BSCU), Thames Tideway Tunnel (TTT) and High Speed Two (HS2). The strengths of developing a collective case studies research lie in that multiple cases offer the opportunity to better understand a phenomenon, and they enhance the ability to build new theories. At the time of the research, the programmes were at different stages of their project life-cycle; hence speculative information was sometimes provided. Our investigation aimed at understanding how innovation is championed and promoted in megaprojects from the perspectives of innovation champions. Using the definition of innovation provided in the introduction, we were interested to explore how innovation is defined in megaprojects and the perspectives of innovation champions on the ways innovation is stimulated and communicated.

\subsection{Data collection and analysis}

Thirty semi-structured interviews have been conducted with innovation managers and champions in different job positions in megaprojects studied, combined with documentations on innovation including innovation strategies, reports and other relevant material. The interviewees were to some extent self-selecting in that they saw themselves as innovation champions. Hence they were willing to talk about innovation and how it might be promoted within megaprojects and more widely. Semi- 
structured interviews and relevant textual data sources capture not only retrospective, present but also future-oriented views (Elsbach and Kramer, 2015). It offers a deep understanding of narratives constructed by innovation champions and their visioning about the ways innovation is championed and promoted in megaprojects. Some interviewees have moved throughout their career across the selected megaprojects. The details of data sources are provided in Table 1.

Table 1. Data sources summary

\begin{tabular}{|c|c|c|}
\hline Megaproject & Data source & Interviewee details \\
\hline \multirow{6}{*}{$\begin{array}{l}\text { London } 2012 \\
\text { Olympics }\end{array}$} & Interview (45mins) & Consultant at Nichols (A) \\
\hline & Interview (60 min) & Principal Programme Supply Chain Manager \\
\hline & Interview (65 min) & Procurement Operation Manager \\
\hline & Interview (60 min) & Procurement Director \\
\hline & Interview (70 min) & Strategic Project Director \\
\hline & Interview (60 min) & Strategic Planning Manager \\
\hline \multirow[t]{10}{*}{ Crossrail } & Lecture & Consultant at Nichols (B) \\
\hline & Interview (60 min) & Chief Executive Officer \\
\hline & Interview (70 min) & Innovation Programme Manager \\
\hline & Interview (70 mins) & Consultant at Nichols (B) \\
\hline & Interview (50mins) & Consultant at Nichols (C) \\
\hline & Interview (50mins) & Programme Controls Director \\
\hline & Interview (57 min) & Strategic Project Director \\
\hline & Interview (60 min) & Procurement Operation Manager \\
\hline & Interview (70 min) & Procurement Director \\
\hline & $\begin{array}{l}\text { Documentation: Details on } \\
\text { Optimised Contractor } \\
\text { Involvement (OCI) process } \\
\text { Innovation Strategy } \\
\text { Value booklet }\end{array}$ & Provided by interviewees \\
\hline Bank Station & Interview (57mins) & London Underground Ltd. Project Manager \\
\hline
\end{tabular}




\begin{tabular}{|c|c|c|}
\hline \multirow{4}{*}{$\begin{array}{l}\text { Capacity Upgrade } \\
\text { (BSCU) }\end{array}$} & Interview (55 min) & Procurement Manager \\
\hline & Interview (60 min) & Programme Manager \\
\hline & Interview (70 min) & Project Manager \\
\hline & $\begin{array}{l}\text { Documentation: } \\
\text { Details on Innovative } \\
\text { Contractor Engagement } \\
\text { (ICE) process }\end{array}$ & Provided by interviewees \\
\hline \multirow{7}{*}{$\begin{array}{l}\text { Thames Tideway } \\
\text { Tunnel (TTT) }\end{array}$} & Interview (80 mins) & Head of Innovation \\
\hline & Interview (45 min) & Innovation Manager \\
\hline & Interview (75 min) & Head of Strategy and Regulation \\
\hline & Interview (70 mins) & Chief Executive Officer \\
\hline & Interview (55 mins) & Strategic and Operational Director \\
\hline & Interview (40 min) & Head of Asset Management \\
\hline & Keynote lecture & Chief Executive Officer \\
\hline \multirow{7}{*}{$\begin{array}{l}\text { High Speed Two } \\
\text { (HS2) }\end{array}$} & Interview (60 min) & Chief Executive Officer \\
\hline & Interview (75 mins) & Innovation Manager \\
\hline & Interview (53 mins) & Senior Manager (A) \\
\hline & Interview (30 mins) & Senior Manager (B) \\
\hline & Interview (60 min) & Head of Innovation \\
\hline & Interview (60 min) & Design director \\
\hline & $\begin{array}{l}\text { Documentation: Details on } \\
\text { Innovation Strategy }\end{array}$ & Provided by interviewee B \\
\hline
\end{tabular}

Each interview aimed to understand the processes and practices employed to champion and promote innovations as well the underlying rational. Guiding questions were:

- How do you define innovation in megaproject?

- How innovation was first introduced and by whom?

- Did you promote innovation in this megaproject and how?

- Did you engage individuals/organisations in the innovation process? 
Further questions were also addressed to understand the contextual and cultural elements of the initiatives and approaches. However, it resulted that the structure of the interviews had to be highly adaptable to:

- $\quad$ Stage of a megaproject at the time of the interview

- $\quad$ Areas spontaneously pursued by the interviewees

We developed detailed case descriptions based on the analysis of the empirical data. The interview transcripts were read by researchers several times over; identifying, analyzing, and reporting themes within the data (Strauss and Corbin, 1990). First we performed open coding to identify initial empirical themes. During this phase, our work was driven by broad questions focusing on how innovation was first introduced and by whom in megaprojects, the innovation team and key roles, how innovation strategy is formulated and formalised, and how innovation become promoted. In this phase of analysis, we identified recurring codes associated with empirical themes and paid attention to innovation champions' own perceptions and narratives. After identifying the initial empirical themes, we performed axial coding to identify similarities and differences in the ways innovation is championed and promoted in five cases. The systematic analysis was reflective in nature by making sense of the identified themes and interpreting them in relation to theory. The analysis allowed for differences between megaprojects to be highlighted and further developments of the theoretical framework.

\section{Findings}

This section illustrates the main findings resulting from the data collected, and describes the set of practices and approaches used in the five case studies to champion and promote innovation.

\subsection{London 2012 Olympics megaproject [2005-2011]}

Our interviewees explained that the London 2012 Olympics megaproject introduced some incremental innovations into the programme and project delivery, but these novel approaches and ideas were not the result of a formalised innovation strategy, rather they were the product of a significant work at the 
front-end to set successful practices and approaches to improve performances. As a result of these early works, the first innovative idea introduced in the scheme was the decision to appoint a delivery partner:

"The delivery partner was the first innovative idea. We brought in the delivery partner early on, it was the CLM. C was CH2M HILL, L was Laing O'Rourke and then M was Mace, so they called themselves CLM. And they were brought in right at the beginning before we engaged in any construction. They brought in global expertise in programme and project management, they had understanding of the previous Olympics, so they were bringing in expertise on techniques, off-site assembling, and so on." (Consultant A, Nichols)

The ODA decided to be a 'thin' intelligent client, to delegate the majority of the responsibilities to the supply chain, and to have a very 'slim' governance. The delivery partner was brought in early on to provide expertise on project and programme management and construction methods. They gave the ODA important advices on how to best deliver the megaproject, such as the recommendation to focus on outcome specifications in order to provide the supply chain with a bounded flexibility to bring innovative ideas. They also suggested that projects be grouped in two categories: infrastructure and venues. For each project, a sponsor - a project director on the client side - was then nominated to integrate the teams and stakeholders involved over the project life-cycle.

Other interviewees revealed that the way the ODA used the Early Contractor Involvement (ECI) also represented an entirely novel and innovative approach. The ECI is a procurement model based on a two-stage Design-and-Build procurement route. During the first stage, contractors explored ideas and new solutions and provided inputs to the design development, including buildability. Whereas at Stage 2 contractors carried out the detailed design and construction. The ECI provided the opportunity to gather contractors' inputs early enough that more effective delivery methods could be identified before any construction was undertaken. Relationships between the ODA and Tier1 contractors were governed by NEC3 (New Engineering Contract, third edition) contracts, 
considered particularly suitable to enable collaboration. NEC is a family of contracts that has become increasingly popular across the UK construction sector and especially among infrastructure projects. The third edition in particular places collaboration and risk-sharing at its foundation with the aim to stimulate good project management. The contracts were incentive-based, so that any savings resulting from improved performances were shared between the two parties. Also, during construction works, a change management process provided flexibility to incorporate emerging ideas:

\footnotetext{
"We brought in a new innovative approach to procurement called 'purchase and supplier engineering' where the client does not sit on top of the supply chain, but sits in the middle. Before you even go to market, you know there is an appetite. It is an innovative way of operating within a supply chain." (Procurement Director in Crossrail who previously worked in Olympics)
}

The individuals involved in innovation process all had experience in different areas. The interviewees further emphasised the role of a 'catalyst' who was the champion of the Olympic Games. He brought all of the people together who spark and inspire each other:

\begin{abstract}
"To certain extent some of megaprojects were shaped by some of the core individuals. So, [Name of CEO] was one of those people who shaped the environment to work in a right way. Having people in senior positions who shape it and get innovation, get collaboration. If you get the wrong person in a senior level what can happen is: "It is going to be the ways we always do this". Innovation would be blocked off." (Consultant B, Nichols)
\end{abstract}

The role of the CEO of Olympics was recognised to be important in shaping the environment where innovation and collaboration can be achieved. The interviewee further reflected that "only looking backward we realised that actually that was innovative. We had to sit down at the end of the Olympics and go: How do we capture that? How do we tell that story?" This shows demonstrates the ways innovation become recognised retrospectively. 
Once there are examples of successful innovative models, products, processes, practitioners think about telling stories and promoting innovation more widely. As soon as the programme was completed, the ODA started sharing the acquired knowledge by building a Learning Legacy platform, an open website where reports, case studies, and documented lessons learned are stored and available. Through the transfer of knowledge and experiences, the aim of the platform is to help improve the performance of the infrastructure sector as a whole. Up to date, there have been a number of innovation case studies, reports being published that capture examples of innovations in London Olympics 2012.

\subsection{Crossrail megaproject [2007-2019]}

When Crossrail started introducing innovation in the programme, tunnelling contractors were already on board and enabling works had already started. At that time, the programme was facing some challenging problems, and the executives asked the Strategic Project Directorate to carry out an internal scan across the organisation to provide recommendations. As an interviewee explained, it was Crossrail's Chief Executive, who first identified innovation as a solution to improve the programme performance. The role of CEO of Crossrail who came with sort of 'innovation mind-set' has been emphasised by most interviewees. They believe that it is the CEO who introduce the word 'innovation' into the vocabulary of the organisation:

"I first came across a programme of innovation when I was in Crossrail. I think [Name of CEO] needs some credit for that. He was working with [Name of academic] at Imperial. All of that led to a series of discussions around the table. Should we do something more structured around innovation and encouraging it and put some processes all of that." (CEO of TTT, former Programme Manager in Crossrail)

"What we did is we actually produced an innovation strategy and it really gave us a guideline what is the process of sharing ideas, investing ideas, developing and promoting those ideas, and doing it safely. I think by creating this process 
that we wrote down, and by creating an environment where it is ok to innovate, people slowly experiment with their own organisations. We were surprised by after the first year we had 500 different innovations, what we call our 'club'” (CEO, Crossrail)

As a result, in 2011 in collaboration with the Imperial College Business School was built to understand why and how Crossrail needed to innovate. As a result, on the one hand Crossrail CEO embarked in a rhetoric effort to promote innovation across Crossrail, and on the other hand they created an innovation strategy that has been published to engage with the supply chain and build the resources:

"The best ideas were likely to originate from the teams - we called it a 'club', so that everybody felt part of the programme, comfortable to contribute and get access to it. We made an early decision to develop the programme with a small core team. So we worked on the concept of a network of champions that could engage locally with their teams, gather ideas and reach back into their teams, company and suppliers to provide the specialist technical resource to review or develop other people's ideas." (Consultant B, Nichols)

The role of the innovation champions was to enable innovative ideas within the supply chain and promote it across different communication channels. The consultant at Nichols (B) has explained the ways innovation was championed and promoted in Crossrail megaproject using a 'bicycle model', shown in Figure 1 below. He reflected: "CEO was riding a bicycle. I am a frame. Two innovation champions are the wheels. Each of the spokes on the wheels are links to the projects". 


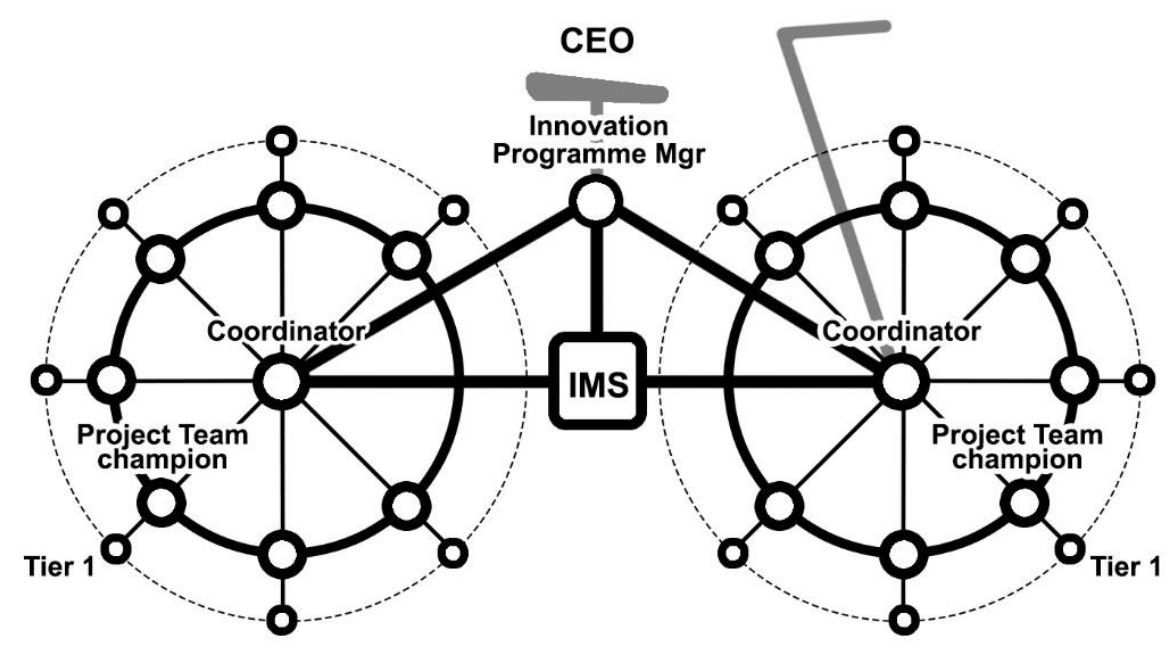

Figure 1. The bicycle-model of innovation champions (developed by Consultant at Nichols B)

The aim was to make ideas easily flow from the periphery to the decision-making levels. For this purpose, they also built an Information Management System (IMS): an online portal (Innovate 18) open to everyone within Crossrail, where ideas could be uploaded and then evaluated and selected. Only ideas that could demonstrate benefits to the scheme or the industry were selected and funded, and to mitigate the risks, innovations were tried and tested in pilot projects before being applied at a large scale. At the moment, Crossrail is working to identify coupling elements with other megaprojects in UK, and engaging in discussions with organisations such as Thames Tideway Tunnel and HS2 to share ideas and innovations. They have also granted selected companies access to the Innovate 18 portal, and they created a learning legacy website clearly inspired by the London Olympics Learning Legacy platform.

\subsection{Bank Station Capacity Upgrade (BSCU) megaproject [2015 - 2021]}

The innovation journey started by London Underground (LU) stimulated by the desire to deliver more value through the project and improve efficiency. LU developed the Innovative Contractor Engagement (ICE), a new procurement model specifically designed to motivate early innovations from the supply chain. ICE has been pioneered on a major upgrade project at Bank Station and the results demonstrate the increase in value that the industry can achieve. As a project manager suggested, the increasing industry focus on innovation and the envisaged benefits encouraged the 
senior management to embark in this initiative, but the novelty of the approach obviously introduced uncertainty and risks and at all levels leadership was demonstrated to give the market and the organisation itself the confidence that the process was going to be successful:

\section{"I think people enjoyed being part of it. They enjoyed doing something a little bit different. So I think people really engaged, but I think it demanded leadership, across all levels. People above me have shown leadership, they needed to give the market the confidence that we would run it properly." (Project Manager, LU)}

ICE was an innovation in the procurement process within LU which originated with an idea from the experienced Programme Director which was presented on two-sides of A4 paper. The programme and project management team worked closely internally with departments in LU and Transport for London's (TfL) external insurance team. They decided to issue all the tender documents as a draft in the first instance. The formal contract document at the start of the process was a confidentiality agreement with each bidder. Workshops were held throughout the pre-contract process to focus on particular areas that LU was concerned about and on what they did not want to have. There were about five months of dialogue where bidders would come forward with ideas to improve the scheme and create better value. Meetings were held to evaluate the proposals with specialists from LU.

The suppliers knew the evaluation criteria which were presented to them as a guideline. This was an opportunity during the dialogue for the bidders to negotiate a contract. The evaluation criteria were focused on the final product (70\%) and the method of building (30\%) - effectiveness and efficiency respectively. The price that the bidders tendered was on the whole life cost in the business case (contract, maintenance, renewal costs, all the risks). An independent observer was present on the meetings to give advice to the bidders about confidentiality. The contracts were re-written based on the negotiations with the bidders. This process allowed competition that led to innovations. Four prequalified bidders were selected for the Bank ICE and they provided four different schemes with significantly different approaches. Two bidders in particular demonstrated innovative thinking. The tender winning bid by Dragados SA provides a more 'Effective Product', increasing the benefits within the business case, and provides a more 'Efficient Method', delivering it faster and cheaper 
compared to original LU Base Case. One example, which embodies both a customer focus and a value-driven mind-set was the decision to invest in a moving walkway in a 90m tunnel. Under traditional procurement this would have appeared as a construction cost of $£ 3 \mathrm{~m}$, while using the product orientated value perspective it provided a benefit of $£ 10.5 \mathrm{~m}$.

A project manager explained that the scope of the competitive dialogue was two-fold. On the one hand it stimulated exploration of new ideas early on in order to identify the optimal delivery strategy and maximise benefits; on the other hand, the negotiation process provided the necessary time to build collaboration within the supply chain. Finally, NEC3 pain/gain target cost contracts were implemented to keep encouraging contractors to develop ideas that could improve the project performances, and a change control process was built to make sure they were captured. Because the ICE proved to be successful, a consultant revealed that the method was being transferred to other schemes within the TfL programme. The project manager has received the Award. He reflected: "I generally found people to be supportive. People wanted to make it work. That made a huge difference." It was a culture of collaboration within the LU and TfL, and with their supply chain. Upon the project completion, the codification of ICE claim to lead to the development of new processes of managing the development of supplier innovation and the promotion of a more collaborative, open and transparent relationship with the market.

\subsection{Thames Tideway Tunnel megaproject [2016-2023]}

The approach to innovation in Thames Tideway Tunnel is to encourage and stimulate an innovation. The reasons for encouraging innovation in the programme is multiple. Firstly, innovative ideas aim to solve problems and increase project performances in terms of time and cost savings. Also, it aims to create value for the community and the people involved, making construction works safer, shorter, less disruptive, etc. Innovation is also seen as a catalyst to create a world-class workforce with benefits not only to the programme, but also to the country overall. And finally, by proving innovative capability to deliver projects, Thames Tideway aims to attract future investments: 
"I was keen to encourage the early career professionals to be heavily engaged with the innovation programme. It seemed to me that we needed to find a natural way of capturing, questioning people early in their career that fitted quite strongly with the concept of innovation and doing things differently, or finding a better way." (CEO, TTT)

"Thames Tideway is supporting people across the alliance to develop their new ideas or applications for funding. Innovative ideas are around creating value in a project, around health and safety, or productivity, or cost, or environment, or well-being." (Innovation Manager, TTT)

Alliance was being developed to enable goal, risk and gain sharing between participants. The alliance would support the innovation journey, and it would also apply to the Optimised Contractor Involvement process, where awarded contractors are asked to provide inputs to improve the current design with the aim of driving efficiency and innovation into the design and the construction methods. For the CEO, the financial model adopted in Thames Tideway is seen as innovative. Others have adopted a future-oriented narrative about a need for a more mature procurement model for encouraging people to put certain percentage of cost to be spend on innovation to enable delivering the contract. At the time of the interviews, Thames Tideway Tunnel has had a small innovation team and just started formalising an innovation strategy, in collaboration with academia. They share Innovate 18 platform developed in Crossrail:

"A network of innovation champions works really well for Crossrail, whether they were embedded or the site teams, different stations, locations. We use the same approach in Tideway. And what you end up is a network of innovation champions in a projects, but what is then actually happens is that it becomes a network of champions across the industry. Crossrail starting the journey, Tideway is picking that up. We are actually encouraging all other infrastructure projects to do the same." (Strategic and Operations Director, TTT) 
A network of innovation champions across infrastructure sector who are committed to an innovation mission is strongly emphasised. The innovation champions tend to change their positions across temporary and permanent organisations in the sector.

The managers interviewed further emphasised the role of storytelling in the process of getting approval from the senior management team to receive funding for development and implementation of innovative ideas:

"Having done this for a couple of years now I have seen probably ten Innovation Forums. I can see that in the end what gets you the funding is storytelling. How you articulate yourself, what the motivations are, the challenges and the benefits. I have seen ideas go to Innovation Forum and people present them in such a way as personal stories - these are the ideas that successfully get funding. In all honesty, sometimes we get ideas which should be really good and should be like an easy win, easy tick, they find it harder because the people presenting it are less skilled in storytelling element. It is not a fair thing but realistic thing. Actually in business a lot of it comes done to people and how you present yourself." (Innovation Manager, TTT)

The interviewee highlighted the ways people articulate themselves and their innovative ideas, demonstrating motivations and enthusiasm when presenting their innovative ideas on innovation forums. It was further reinforced that innovation is promoted through web-sites, innovation platforms and communication campaigns:

"Last year we run two campaigns around, the first was Dragon Den's event, we had 4 Dragons. It is the appeal for presenting your idea to CEO, that promotes it in itself. You talk about senior level support. You have got an opportunity to present to CEO your idea of innovation. That means something. We had a lot of ideas in a month after this event. We went to the actual studio of Dragon Den used to be filmed. There is a whole theatrical aspect around it as well which 
people tend to like. A second campaign we run was called 'mission possible'.

That was all about carbon reduction and sustainability and environmental value.

It is a fun. We had again another 30-50 ideas come through just from that campaign supported by the champions."

Dragon's Den events in Thames Tideway aim to stimulate the team to pitch their own innovative ideas to senior management team to get support and funding. People get rewarded and recognised for their innovative ideas, i.e. it could be a 'mention', a week blog, or picture in the staff newspaper. For wider stakeholders and public, Thames Tideway is constructing a narrative about how they innovate and improve. There are a number of innovation champions recognised within the Tideway from different sections, e.g. legal and finance, human resources, health and safety, environment, sustainability. The role of champions is to communicate innovation and support colleagues in their teams to bring forward innovative ideas. Thames Tideway Tunnel has an innovation thinking group who meet together and decide which ideas are rejected and which are recommended to the innovation forum. Innovation champions play an important role in the assessment and supporting innovative ideas. The visibility of CEO and his team is seen important by innovation managers:

"Generally, senior managers are all supportive of innovation. But it is very much down to how visible you are. Because you can be supportive, but you have to be vocally visible to make a difference that we are all working for you. You can say in an email that you are supportive of innovation. But if you do not send an email to your whole hundreds of people who are working for you, or standing on your team meetings and say: I want people to do innovation and I want you to think about doing things in new ways. And if you only talking about cost, schedule, then it is not right cultural message." (Innovation Manager, TTT)

"Our chief executive is a very passionate individual, a real leader. And he is setting a tone for the project and a tone for the organisation, and within that tone 
he does want some risk been taken?" (Head of Strategy and Regulation, Thames

Tideway Tunnel)

It is argued that senior leaders' talk or narration should reflect their actions. Innovation is promoted ad-hoc through different communication channels: web-site, innovation portals and platforms, intranet, social media, and events.

\subsection{High Speed Two (HS2) megaproject [2016-2032/2033]}

The way HS2 has positioned innovation is use it as an enabler to deliver strategic objectives of the Government programme. It works closely with Industrial Strategy. HS2 aimed to take a different approach to innovation from other megaprojects. They distinguish themselves as embedding innovation capabilities much earlier than for example in Crossrail. Innovation is defined as "going beyond the industry best practice". The CEO of HS2 has reflected:

"For me it is about creating the right environment, empowering people, giving them the budget and accountability. But also challenging around the risk question. Making sure I have got some independent perspectives on risk that would be used to judge whether innovation is appropriate or not."

A small innovation team has been established and then has expanded: from one Innovation Manager to three Innovation Managers and Head of Innovation. The Innovation Managers interviewed claimed that before they arrived it was not any innovation, but more about lessons learned and value management. It was not at all an overall strategic process; there were no innovation portals or other mechanisms. Innovations are aimed at delivering better quality outcomes, e.g. social benefits, cheaper railway. Suppliers have contractual obligations to innovate and HS2 is also looking at bringing others who are not linked contractually. HS2 runs innovation days where people are brought together, contractors, suppliers and external people. Innovative ideas re reviewed weekly to evaluate which ideas will get funding and progress. Similarly to Thames Tideway Tunnel, HS2 runs Dragon Den days. Innovation is also promoted via videos, lunch and learn sessions where they talk about an 
approach to innovation. The Head of Innovation has reflected on the journey of transformation by reinforcing the need for innovation and future intentions:

"I think the way we are managing an innovation and strategy and the approach is very different than other projects done in this industry. We are in the process, and the supply chain coming on board, so there is a time required for them to absorb all this information and start to feel that this is part of their day job. When we reinforced why this is really important, they started to give us some ideas but maybe not particular great quality. Now we are seeing improvement in quantity and quality and start to get that sort of engagement. For where we are in the life cycle of a programme I am reasonably confident, there is always more work to do, and I never be satisfied that we have the culture and the environment right because you never will."

There are two-phases of the programme. The 'big risk' innovations are perceived likely to succeed in phase one; the innovation team is currently working on developing this approach in phase two. There is also a distinction being made between leading innovation in three levels: a) project where essentially they are 'buying' innovation; b) programme where they are proactively leading the identification of relevant ideas and supporting their deliver; c) industry where they are sourcing those opportunities working with others in collaboration to deliver innovations for the benefit of the industry.

Of further note is the role of articulating a clear narrative around why HS2 is important and its mission both internally and externally by senior leaders:

"Because HS2 is such high-profile and contentious, a key part of being a leader is to actually to be able to articulate a very clear narrative around why HS2 is important. Not just for the purpose of promoting it externally, but internally as well, to motivate people. People are knowing why they are doing it, and actually make sure we are delivering the right thing. Having a very clear narrative absolutely has been very important." (CEO, HS2). 
In summary, CEOs are recognised by most interviewees as influential to the innovation approaches and strategies in megaprojects. They tend to move around megaprojects and thinking about new generation who will champion and promote innovation:

"It is a revolving door of people. That in itself brings a new set of questions because [names of CEOs of a few UK megaprojects] are a generation that this is the last time they will do it. Then the next generation moves on. It is a constant revolving door, and a turnover of people." (Programme Controls Director, Crossrail)

Table 2 summarises the ways innovation is championed and promoted in five megaprojects

Table 2. The ways innovation is championed and promoted in five megaprojects

\begin{tabular}{|c|c|c|c|c|}
\hline Megaprojects & $\begin{array}{l}\text { Approaches to } \\
\text { innovation }\end{array}$ & Innovation strategy & $\begin{array}{l}\text { Innovation team and } \\
\text { championing }\end{array}$ & $\begin{array}{l}\text { Ways of promoting } \\
\text { innovation }\end{array}$ \\
\hline $\begin{array}{l}\text { London } \\
2012 \\
\text { Olympics }\end{array}$ & $\begin{array}{l}\text { Delivery partner and } \\
\text { early contractor } \\
\text { involvement } \\
\text { Incremental } \\
\text { innovations }\end{array}$ & $\begin{array}{l}\text { Embedded in } \\
\text { business strategy, but } \\
\text { not formalised }\end{array}$ & $\begin{array}{l}\text { No formal innovation } \\
\text { manager roles } \\
\text { People in senior } \\
\text { positions } \\
\text { championed } \\
\text { innovation } \\
\text { 'Catalyst' who } \\
\text { championed } \\
\text { programme }\end{array}$ & $\begin{array}{l}\text { Learning Legacy } \\
\text { platform } \\
\text { Publicly available } \\
\text { website } \quad \text { where } \\
\text { reports, and } \\
\text { studies } \\
\text { documents are } \\
\text { represented }\end{array}$ \\
\hline Crossrail & $\begin{array}{l}\text { Introduced innovation } \\
\text { programme later in } \\
\text { the life cycle } \\
\text { Engagement with } \\
\text { academics }\end{array}$ & $\begin{array}{l}\text { First to formalise } \\
\text { innovation strategy }\end{array}$ & $\begin{array}{l}\text { CEO who came with } \\
\text { 'innovation mind-set' } \\
\text { and introduced } \\
\text { innovation into } \\
\text { vocabulary } \\
\text { Innovation programme }\end{array}$ & $\begin{array}{l}\text { Innovate } 18 \\
\text { online portal } \\
\text { Innovation } \\
\text { forums } \\
\text { Learning Legacy } \\
\text { platform }\end{array}$ \\
\hline
\end{tabular}




\begin{tabular}{|c|c|c|c|c|}
\hline & & & $\begin{array}{l}\text { manager } \\
\text { 'Club' }- \text { a small } \\
\text { innovation team } \\
\text { Innovation Hub }\end{array}$ & \\
\hline $\begin{array}{l}\text { Bank } \\
\text { Station } \\
\text { Capacity } \\
\text { Upgrade } \\
\text { (BSCU) }\end{array}$ & $\begin{array}{l}\text { The desire to deliver } \\
\text { more value to } \\
\text { improve efficiency } \\
\text { Innovative Contractor } \\
\text { Involvement (ICE) } \\
\text { with confidentiality } \\
\text { agreements } \\
\text { Innovation was } \\
\text { driven by competition }\end{array}$ & $\begin{array}{l}\text { Embedded in } \\
\text { business } \\
\text { strategy, but not } \\
\text { formalised }\end{array}$ & $\begin{array}{l}\text { No formal innovation } \\
\text { manager roles }\end{array}$ & $\begin{array}{l}\text { Corporate report on } \\
\text { Innovative } \\
\text { Contractor } \\
\text { Involvement (ICE) }\end{array}$ \\
\hline $\begin{array}{l}\text { Thames } \\
\text { Tideway } \\
\text { Tunnel } \\
\text { (TTT) }\end{array}$ & $\begin{array}{l}\text { Innovative approach } \\
\text { from the front-end } \\
\text { Encouraging and } \\
\text { stimulating } \\
\text { innovation }\end{array}$ & $\begin{array}{l}\text { Embedded in } \\
\text { business strategy, } \\
\text { but not yet } \\
\text { formalised }\end{array}$ & $\begin{array}{l}\text { Head of Innovation } \\
\text { A small team of } \\
\text { innovation } \\
\text { managers and teams } \\
\text { The role of CEO } \\
\text { who has previously } \\
\text { worked in Crossrail } \\
\text { is emphasised }\end{array}$ & $\begin{array}{l}\text { Share Innovate } 18 \\
\text { platform developed } \\
\text { in Crossrail } \\
\text { Innovation forums } \\
\text { Communication } \\
\text { campaigns } \\
\text { Dragon Den's } \\
\text { events } \\
\text { Innovation } \\
\text { promoted ad hoc } \\
\text { through various } \\
\text { communication } \\
\text { channels }\end{array}$ \\
\hline $\begin{array}{l}\text { High } \\
\text { Speed } \\
\text { Two } \\
\text { (HS2) }\end{array}$ & $\begin{array}{l}\text { Distinguish } \\
\text { themselves from } \\
\text { Crossrail to take an } \\
\text { Innovative approach } \\
\text { from the front-end }\end{array}$ & $\begin{array}{l}\text { Embedded in } \\
\text { business strategy, } \\
\text { but not yet } \\
\text { formalised }\end{array}$ & $\begin{array}{l}\text { From one } \\
\text { innovation to three } \\
\text { innovation } \\
\text { managers and Head } \\
\text { of Innovation }\end{array}$ & $\begin{array}{l}\text { Innovation Forums } \\
\text { Dragon Den's } \\
\text { events }\end{array}$ \\
\hline
\end{tabular}




\begin{tabular}{|l|l|l|l|}
\hline & $\begin{array}{l}\text { rather than later in } \\
\text { the life cycle } \\
\text { Enabler to deliver } \\
\text { strategic objectives } \\
\text { set by the } \\
\text { Government and } \\
\text { Industrial Strategy }\end{array}$ & $\begin{array}{l}\text { The role } \text { CEO is } \\
\text { emphasised in the } \\
\text { innovation } \\
\text { programme }\end{array}$ & \\
\hline
\end{tabular}

\section{Discussion}

\subsection{Championing innovation in megaprojects}

The empirical data demonstrate that innovations in megaprojects are driven by their special purpose and associated narrative about mission, solving problems, satisfying customers and users, targets set by the Government and changes in regulations, and performance improvement. Innovation was commonly defined as new product, process or service in the specific context (rather than new to the world), as a step change or best practice that creates value. Each megaproject aims to be unique in the way they champion and promote innovations, yet shared approach and commitment to innovation mission is encouraged across megaprojects. For example, in Olympics 2012 the emphasis was placed on the delivery partner and early contractor involvement as innovative approaches. Innovation was embedded in the business strategy, but was not formally published. Crossrail was the first formalising an innovation strategy. But it has been critiqued by other megaprojects as starting introducing innovation programme much later in the life-cycle. Whereas in Thames Tideway and High Speed Two innovative capabilities have started to be built at the front-end of the life-cycles building upon the lessons learned from Crossrail. From the perspectives of experienced interviewees, forming an innovation strategy at the front-end is encouraged in future megaprojects.

Among most cases there was a strong sense of recognised importance of leadership in developing and implementing innovation programmes and strategies. CEOs have been emphasised to play an important role in introducing the label 'innovation' into the vocabulary of megaprojects 
(sensemaking labelling, Weick, 1995). At the front-end of megaprojects narratives about their purpose/mission are constructed (sensegiving, Weick, 1995) that set the coherent vision for innovation strategies. The dialogues between those in senior positions (CEOs and their teams), innovation managers, champions and their teams, and academics shape the ways innovations is championed and promoted in megaprojects. It is through interactive dialogues that the identity of being and becoming 'innovative' is (re)constructed (Chia, 1995); Humphreys and Brown 2002. Innovation champions construct narratives about organisational identity of how megaprojects innovate and improve.

By emphasising the interactive dialogues and the resources of language in organizing processes, Karl Weick's concept of sensemaking forms part of the 'linguistic turn' in organisation studies (Czarniawska, 2006; Weick et al., 2005) and project management studies (Havermans et al., 2015; McKenna and Metcalfe, 2013). Enninga and van der Lugt's (2016) research narratives in innovation projects, but notably fall short of seeing innovation as a discursive construct, preferring to position innovation projects as a supposed to projects more generally. Metaphors have, among other discursive resources, been pointed out as relevant linguistic devices applied in order to make sense of events, be it in everyday or in academic theory construction (Cornelissen et al., 2008; Heracleous and Jacobs, 2008). The metaphor of bicycle is used to explain the way innovation is championed in Crossrail megaproject by innovation champions and their teams.

Innovation champions are seen to play an important role in the innovation process throughout the life-cycles of megaprojects. We found that both top-down and bottom-up innovation championship (Day, 1994) are critical to building and enhancing innovation capabilities in megaprojects. The extant studies are largely silent about the informal roles and identities of innovation champions in the context of megaprojects (Blayse and Manley, 2004; Leiringer and Cardellino, 2008; Winch, 1998). We build upon the conclusion by Davies et al. (2009) about the role of strong leadership in building and enhancing innovative capabilities of megaprojects, and by Gann et al. (2017) about strategic processes used by managers to address the risks and opportunities involved in megaproject management. The particular contribution of this paper is in the role 
innovation champions in megaprojects and demonstrating different ways of championing and promoting innovation. We found that storytelling plays an important role for innovators who come up with new ideas, when self-presenting themselves and their innovative ideas to get approval from senior management and/or funding from investors. Innovation champions in megaprojects are enthusiastically and proactively involved in encouraging and stimulating innovative ideas, and promoting innovation narratives to different audiences. The empirical evidence show that champions in megaprojects are actively organise innovation forums, portals and communication campaigns where everyone in an organisation has an opportunity to present innovative ideas and get support from others. This contributes to emerging innovation studies on the role of narratives in the innovation process (Bartel and Garud, 2009; Garud and Turunen, 2018) and project management literature on innovation narratives (Enninga and van der Lug, 2016).

\subsection{Megaprojects stimulating innovation in supply chain}

Innovation was closely related to collaboration; the interviewees emphasised the alliance capabilities in championing innovation in megaprojects (Köhtamäki et al., 2018). Both the ECI and the OCI used in the London Olympics and Crossrail aimed to incentivise contractors and suppliers to research and develop new ideas. The incentive was created by using pain-gain share NEC3 contracts, which were able to offer awarded contractors and suppliers the opportunity to benefit from any cost saving resulting from the innovations introduced. Also, the NEC3 suite was specifically selected to create an environment of cooperation between the client organisation and the supply chain which was believed to be instrumental to encourage innovation. Compared to other types of contracts, NEC3 contacts in fact clearly require that all parties act collaboratively in a spirit of mutual trust. The ECI and the OCI also enabled an early engagement with contractors that helped capture novel solutions before any construction work had started.

Whilst Thames Tideway and HS2 were planning to use the same procurement models as part of their innovation strategies, LU developed a totally novel approach. With the ICE they started the engaging process well before contracts were awarded, and the negotiated dialogue used offered 
greater time for exploration and team building. But the fact that incentives were embedded into the tendering process represented the real novelty. Differently from the other procurement strategies where gainsharing encouraged suppliers to explore novel solutions, the main incentive to innovate introduced by the ICE was in fact the award of the contract itself.

Despite their differences, the ECI, OCI and ICE all were the result of structured processes used to identify how existing procurement practices could be used, improved or recombined to encourage suppliers to innovate. In order to do so, clients had to identify the type of formal and informal relationships they wanted to enable, when contractors' engagement was desired, and what incentives could be used to encourage exploration of ideas. With reference to the literature of large infrastructure projects, we can therefore conclude that over the engaging window the client's commercial capabilities are critical, and in particular their contractual and relational capabilities which are defined as the ability to select appropriate contracting strategies and procurement methods and the ability to informally interact with suppliers (Winch and Leiringer, 2015).

Although the NEC3 contracts used in the London Olympics and the Bank Station Capacity Upgrade provided an incentive for suppliers to continue exploring new solutions and improve performances, no structured initiatives were developed to actively encourage suppliers and contractors after contracts were awarded. A change control function was built to ensure further ideas were captured, but both the ODA and LU decided to focus the active exploration on the initial stages only and minimise it as construction works started. In contrast, the bicycle model developed by Crossrail allowed them to systematically manage the innovations offered by the supply chain over the construction phase too.

An innovation champion network was built to motivate exploration; Innovate 18 was designed to capture, assess and select ideas, a 'club' of representatives from the supply chain was created to ensure funds, and a programme manager was identified to oversee the whole process, ensure governance and address IPR issues. Inspired by Crossrail, Thames Tideway were planning to transfer most of these components and like HS2 they were starting to define the innovation team 
structure and responsibilities, a systematic process to funnel, assess and implement ideas, and ways to build an innovation budget. We can therefore argue that key to the leveraging window (Davies et al., 2014) is the owner's governance capability applied within the temporary organisation (Winch, 2014). In order to effectively mobilise delivery partners, contractors, and suppliers, clients need to design a distinct set of roles and responsibilities, tools, methods and processes, and control functions, to actively motivate and support innovation activities within the supply chain.

\subsection{Promoting innovation in megaprojects}

At the back-end of megaprojects, the narrative of mission gets revisited, and innovative approaches and practices become recognised and promoted more widely. For example, in Olympics megaproject procurement called 'purchase and supplier engineering' retrospectively was seen as innovative (retrospective sensemaking, Weick, 1995). The London Olympics Learning Legacy represented the first example of a structured lessons learned and innovation sharing system open to everyone, and it motivated other organisations to do the same. In all five projects we identified the desire to externalise the knowledge developed to help other projects within the industry and potentially outside the industry itself. Crossrail emulated the London Olympic Learning Legacy by building a similar platform as the project neared completion. In addition, by allowing other companies to access Innovate 18 they already started sharing best practices as works were still underway. Although they were still in early stages, Thames Tideway and HS2 also considered enabling knowledge transfer to other organisations. This reflects the five rules for managing large complex projects by Davies et al. (2017) who focus on how innovation might be integrated in contemporary megaprojects. The innovation networks they were planning to create, whilst supporting knowledge gaining, was also supposed to make knowledge available to the other members of the network. The exchanging window (Davies et al., 2009) represents the opportunity for project owners to share the innovations produced with other organisations in the market to support other projects. This emphasises the connection between innovation and learning capabilities in megaprojects. A network of innovation champions who move across temporary and permanent owner and supply organisations within the infrastructure sector play an important role in enhancing innovation and learning capabilities. 
The empirical data demonstrate that innovation is promoted in megaprojects across different communication channels. A number of publications on innovation in megaprojects are available on the web-sites and internal textual materials. The empirical evidence shows a variety of ways megaprojects organise innovation forums, portals, communication campaigns and Dragon Den's events where everyone in an organisation has an opportunity to present innovative ideas, get support from others and receive funding for further development and implementation of innovations. The communication campaigns and Dragon Den's events have been used for the first time in Thames Tideway and later in HS2 and are recognised as focused conversations which generate valuable innovations. The innovation ecosystem in megaprojects is becoming formed, placing London in an attractive position becoming recognised as innovative.

\section{Conclusions}

Megaprojects are an important area of project studies (Geraldi and Söderlund, 2018). There is a growing interest in innovation management in megaprojects (Davies et al., 2014; Davies et al., 2017), yet much to be explored in this area of research. Our paper contributes to the literature on innovation in megaprojects by better understanding the ways innovation is championed and promoted in megaprojects. We showed the key differences and connectivity across the five selected UK megaprojects in their approaches to innovation. We captured innovation champions' own perspectives on capabilities and competencies required by megaprojects to stimulate and encourage innovations.

Further research may deepen our understanding as to the ways megaprojects can enhance innovation capabilities and competencies. This can be achieved through follow-up interviews with innovation champions throughout the life-cycle of megaprojects, combined with participant observations, textual and visual materials. Future studies may also explore further a network of innovation champions in the business ecosystem. The role and nature of innovation narratives in megaprojects merit further attention. With more and more megaprojects planned for the future, innovation, collaboration and learning legacies are critical to help future megaprojects more easily gather learning, experiences, and so on, that can be combined in innovative solutions and ultimately raise the industry's performances and hence the benefits to our communities. 


\section{References}

Bartel, C. A., Garud, R. 2009. The role of narratives in sustaining organizational innovation. Organization Science, 20(1), 107-117.

Blayse, A.M., Manley, K. 2004. Key influences on construction innovation. Construction Innovation, 4(3), 143-154.

Bossink, B. A. G. 2004. Managing drivers of innovation in construction networks. Journal of Construction Engineering and Management, 130(3), 337-345.

Brockmann, C., Brezinski, H., Erbe, A. 2016. Innovation in construction megaprojects. Journal of Construction Engineering and Management, 142(11), 04016059.

Brookes, N., Sage, D., Dainty, A., Locatelli, G., Whyte, J. 2017. An island of constancy in a sea of change: Rethinking project temporalities with long-term megaprojects. International Journal of Project Management, 35(7), 1213-1224.

Chia, R. 1995. From modern to postmodern organizational analysis. Organization Studies, 16(4), 579604.

Cornelissen, J. P., Oswick, C., Christensen, L. T., Phillips, N. 2008. Metaphor in organizational research: Context, modalities and implications for research. Organization Studies, 29(1), 7-22.

Czarniawska, B. 2006. A golden braid: Allport, Goffman, Weick. Organization Studies, 27(11), $1661-74$.

Davies, A., MacAulay, S., DeBarro, T., Thurston, M. 2014. Making innovation happen in a megaproject: London's Crossrail suburban railway system. Project Management Journal, 45(6), 25-37.

Davies, A., Mackenzie, I. 2014. Project complexity and systems integration: Constructing the London 2012 Olympics and Paralympics games. International Journal of Project Management, 32(5), 77390. 
Davies, A., Gann, D., Douglas, T. 2009. Innovation in megaprojects: systems integration at London Heathrow Terminal 5. California Management Review, 51(2), 101-125.

Davies, A., Dodgson, M., Gann, D. M., MacAulay, S. 2017. Five rules for managing large, complex projects. MIT Sloan Management Review, 59(1), 73-78.

Day, D. L. 1994. Raising radicals: Different processes for championing innovative corporate ventures. Organisation Science, 5(2), 148-172.

Dodgson, M., Gann, D., MacAulay, S., Davies, A. 2015. Innovation strategy in new transportation systems: The case of Crossrail. Transportation Research Part A: Policy and Practice, 77, 261-275.

Egan, Sir J. 1998. Rethinking construction. HMSO, London.

Elsbach, K. D., Kramer, R. M. 2015. Handbook of qualitative organizational research: Innovative pathways and methods. London: Routledge.

Enninga, T., van der Lugt, R. 2016. The innovation journey and the skipper of the raft: about the role of narratives in innovation project leadership. Project Management Journal, 47(2), 103-114.

Flyvbjerg, B. 2014. What you should know about megaprojects and why: An overview. Project Management Journal, 45(2), 6-19.

Flyvbjerg, B. 2017. The Oxford Handbook of megaproject management (eds.). Oxford University Press, Oxford, UK.

Flyvbjerg, B., Bruzelius, N., Rothengatter, W. 2003. Megaprojects and risk: An anatomy of ambition. Cambridge University Press, Cambridge, UK.

Gann, D., Davies, A., \& Dodgson, M. 2017. Innovation and flexibility in megaprojects, In B. Flyvbjerg The Oxford Handbook of megaproject management, ed., Oxford University Press, Oxford, UK, pp. 313-337.

Garud, R., Turunen, M. 2018. The banality of organizational innovations: Embracing the substanceprocess duality. Innovation: Organization \& Management, 19, 31-38. 
Geraldi, J., Söderlund, J. 2018. Project studies: What it is, where it is going. International Journal of Project Management, 36(1), 55-70.

Gil, N., Miozzo, M., Massini, S. 2012. The innovation potential of new infrastructure development: An empirical study of Heathrow airport's T5 project. Research Policy, 41(2), 452-466.

Havermans, L. A., Keegan, A., Den Hartog, D. N. 2015. Choosing your words carefully: Leaders' narratives of complex emergent problem resolution. International Journal of Project Management, 33(5), 973-984.

Heracleous, L., Jacobs, C. D. 2008. Understanding organizations through embodied metaphors. Organization Studies 29(1), 45-78.

Howell, J. M., Higgins, C. A. 1990. Champions of technological innovation. Administrative Science Quarterly, 35(2), 317-341.

Humphreys, M., Brown, A. D. 2002. Narratives of organizational identity and identification: A case study of hegemony and resistance. Organization Studies, 23(3), 421-447.

Jenssen, J. I., Jörgensen, G. 2004. How do corporate champions promote innovations? Journal of Innovation Management, 8(1), 86-111.

Köhtamäki, M., Radetino, R., Möller, K. 2018. Alliance capabilities: A systematic review and future research directions. Industrial Marketing Management, 68(1), 188-201.

Latham, Sir M. 1994. Constructing the team. HMSO. London.

Leiringer, R., Cardellino, P. 2008. Tales of the expected: Investigating the rhetorical strategies of innovation champions. Construction Management and Economics, 26(10), 1043-1054.

Lundin, R.A., Söderholm, A. 1995. A theory of the temporary organization. Scandinavian Journal of Management, 11(4), 4347-455.

Jones, M., Saad, M. 1998. Unlocking specialist potential. Thomas Telford, Wallington, Surrey. 
McKenna, A., Metcalfe, M. 2013. The linguistic turn in project conceptualization. International Journal of Project Management, 31(8), 1154-1162.

Nam, C., Tatum, C. 1997. Leaders and champions for construction. Construction Management and Economics, 15(3), 259-270.

Orstavik, F., Dainty, A., Abbott, C. 2015. Construction innovation. Chichester, UK: John Wiley \& Sons.

Sanderson, J. 2012. Risk, uncertainty and governance in megaprojects: A critical discussion of alternative explanations. International Journal of Project Management, 30(4), 432-443.

Schon, D. A. 1963. Champions for radical new inventions: It is in the nature of a large organization to oppose upsetting change and innovation; answer to the problem. Harvard Business Review, 41, 77-86.

Sergeeva, N. 2016. What makes an 'innovation champion'? European Journal of Innovation Management, 19(1), 72-89.

Sergeeva, N. and Roehrich, J. 2018. Learning in temporary multi-organizations: Improving performance and constructing identities. Industrial Marketing Management, 31 (in press).

Söderlund, J. 2004. Building theories of project management: past research, questions for the future. International Journal of Project Management, 22(3), 183-191.

Söderlund, J. 2017. A reflection on the state-of-the-art in megaproject research: The Oxford Handbook of megaproject management. Project Management Journal, 48(6), 132-137.

Strauss, A., Corbin, J. 1990. Basics of grounded theory methods. Beverly Hills, CA: Sage.

Unger, B. N., Rank, J., Germünden, H. G. 2014. Corporate innovation culture and dimensions of project portfolio success: The moderating role of national culture. Project Management Journal, 45(6), 38-57.

Weick, K. E. 1995. Sensemaking of organizations. Thousand Oaks, CA, USA: Sage Publications. 
Weick, K. E., Sutcliffe, K. M., Obstfield, D. 2005. Organizing and the process of sensemaking. Organization Science, 16(4), 409-421.

Winch, G. M. 1998. Zephyrs of creative destruction: understanding the management of innovation in construction. Building Research \& Information, 26(5), 268-279.

Winch, G. M. 2014. Three domains of project organizing. International Journal of Project Management, 32(5), 721-731.

Winch, G. M., Leiringer, R. 2015. Owner project capabilities for infrastructure development: A review and development of the 'strong owner' concept. International Journal of Project Management, 34(2), 271-281.

Wolstenholme, A. 2009. Never waist a good crisis. A review of progress since Rethinking Construction and thoughts for our future. Constructing Excellence, London, UK.

Worsnop, T., Miraglia, S., \& Davies, A. (2016). Balancing Open and Closed Innovation in Megaprojects: Insights from Crossrail. Project Management Journal, 47(4), 79-94.

Yin, R. K. 2014. Case Study Research. Design and Methods. SAGE, Los Angeles. 